\title{
1 Practical Ethics in Sidgwick and Kant
}

\author{
Anthony Skelton
}

Sidgwick engaged both Kant's theoretical and his practical philosophy. The effect of the engagement with Kant's theoretical philosophy was not insignificant. Sidgwick opined that post-Kantian German metaphysics was "a monstrous mistake," and that "we must go back to Kant and begin again from him" (Sidgwick and Sidgwick 1906, 151). ${ }^{1}$ Sidgwick found the study of Kant's metaphysics edifying, declaring "I shall always look on him [Kant] as one of my teachers" (Sidgwick and Sidgwick 1906, 151; also 159) and that the study of Kant's theoretical system provides "a most valuable metaphysical education" $(1905,30)$. He was, however, unwilling to call himself a Kantian in metaphysics (Sidgwick and Sidgwick 1906, 151).

$\mathrm{He}$ described the Critique of Pure Reason as putting forward a "false system" (Sidgwick and Sidgwick 1906, 386) and Kant's work in the book as "deficient in . . self-criticism" $(1883,72)$. While Kant is, Sidgwick said, "one of the most original, penetrating, ingenious, and laboriously systematic of modern thinkers ... he is a profoundly inconsistent thinker, profoundly unaware of his own inconsistency" (1905, 30-31). Because Sidgwick's work on Kant's metaphysics focuses mostly on these inconsistencies rather than on building a rival system with Kantian inspiration, it is unsurprising to find it described as "not of the first importance" (Passmore 1975,195 ).

Sidgwick's engagement with Kant's practical philosophy is, while critical, more central to his main research preoccupations and therefore likely of more enduring interest. He claimed Kant as one of his moral philosophical "masters" (ME xx) and he addresses many of Kant's most important views in ethics. Sidgwick worked out a comprehensive rival ethical system in which he was clear about what he did and did not accept in Kant's practical philosophy and why.

Many of Sidgwick's criticisms of Kant are of lasting value. Sidgwick's objection that in his ethics Kant unwittingly relies to his peril on two distinct conceptions of freedom, good freedom and neutral freedom, is among the most noteworthy (ME 512). ${ }^{2}$ 


\section{Anthony Skelton}

One is free on the first conception only when one is motivated to do the right thing because it is the right thing and not because of some desire one has for some end (e.g., KpV 5:78; G 4:446-447). ${ }^{3}$ But, Sidgwick argues, if one is free only when one acts from duty, one cannot be held responsible for wrong actions since such actions are never done from duty; they always involve motivation by inclination, in which case one is determined by sensible motives and therefore not free.

One is free on the second conception when one has the power to choose right or wrong (e.g., $\mathrm{KpV} \mathrm{5:98).} \mathrm{Kant} \mathrm{requires} \mathrm{this} \mathrm{kind} \mathrm{of} \mathrm{free-}$ dom, Sidgwick contends, in order to hold agents responsible for wrongdoing. The difficulty, for Kant, is that neutral freedom implies that one is free even when one acts wrongly, and if Kant admits this, he has to agree "the scoundrel must exhibit and express his characteristic self-hood in his transcendental choice of a bad life, as much as the saint does in his transcendental choice of a good one" (ME 516). In this case the "spiritstirring appeal to the sentiment of Liberty [that Kant gets by connecting freedom and motivation by reason] must be dismissed as idle rhetoric" (ME 516).

Sidgwick's objection is vexing to Kant's admirers; accordingly, it has received detailed attention. ${ }^{4}$ Less sustained attention has been paid to Sidgwick's other interactions with Kant's ethics. Kant and Sidgwick are noteworthy for having written on both theoretical and practical ethics, making it possible to fruitfully compare and contrast them on a range of ethical issues. In this chapter, I explore the relationship between the two on some issues in practical ethics (broadly understood).

In $\$ I$, I outline the main element of Kant's theoretical ethics that Sidgwick endorsed. In $\mathbb{S} \mathbb{S I}$ and III, I outline and adjudicate two of their sharpest disagreements in practical ethics, on the permissibility of lying and on the demands of beneficence. In $\mathbb{I V}, \mathrm{I}$ argue that compared to Kant, Sidgwick has a better strategy for dealing with disagreement in practical ethics. $\$ V$ sums things up.

\section{I}

For Sidgwick, claiming someone as a master did not involve hagiography or signal agreement. Of his masters, Mill is perhaps the most prominent. Through Mill, Sidgwick became an adherent of utilitarianism, the view that the sole criterion of morality is the promotion of aggregate happiness (ME xvii; 1998, 8). Sidgwick nevertheless held a dubious opinion of Mill's work in ethics. In an obituary he wrote for Mill, he remarks that Utilitarianism is "hastily put together, and the system seems incompletely reasoned and even incoherently expounded" (Sidgwick 1873, 193).

Sidgwick was especially dissatisfied with Mill's proof of utilitarianism. Mill argued that each individual's happiness is alone good because she 
desires only it, from which he famously inferred that the sum or aggregate of each individual's happiness is the only good and therefore what we ought to promote (Mill 1969, 235-239). Sidgwick rightly noted that there is a gap in this argument. From the fact that each individual's happiness is good it does not follow that the sum of each individual's happiness is good. This is because no desire for the sum of happiness is present in the aggregate. The gap in Mill's argument would be closed, on Mill's own reasoning, only if the aggregate desired its own happiness.

But, Sidgwick complains,

an aggregate of actual desires, each directed towards a different part of the general happiness, does not constitute an actual desire for the general happiness, existing in any individual; and Mill would certainly not contend that a desire which does not exist in any individual can possibly exist in an aggregate of individuals. There being therefore no actual desire . . . for the general happiness, the proposition that the general happiness is desirable cannot be in this way established.

(ME 388)

Sidgwick disagreed with Mill's view that one can infer claims about what is valuable from claims about what is desired. The former argued that instead the justification of the claim that happiness is the only good "is properly ... reached . . . by a more indirect mode of reasoning" (ME 389). The manner of reasoning involves, for Sidgwick, appeal to "intuitive judgment after due consideration" and "a comprehensive comparison of the ordinary judgements of mankind" (ME 400). The move from the claim that each individual's happiness is good to the claim that the happiness of the aggregate is good and therefore what we ought to promote is justified, on Sidgwick's view, only by appeal to the intuitively known self-evident proposition that one ought to aim at good generally not merely at a particular part of it, giving equal value to equal quantities of happiness (ME 382).5 Sidgwick called this the axiom or principle of rational benevolence. $^{6}$

Although Sidgwick appealed to intuition to justify utilitarianism, and so rejected Mill's empiricism, his appeal did not allay his most pressing concern. He was struck by the difficulty of reconciling duty and selfinterest. He fell under the sway of another master, Joseph Butler. Sidgwick rejected the anti-utilitarian elements of Butler's theory of virtue and vice, thinking that together with a great many other elements of common-sense morality these could be incorporated into utilitarianism ( $M E x x, 423-459,496)$. But he agreed with Butler in holding that there is a self-standing obligation to promote one's own happiness that competes with other rational demands (ME 7,119). In some cases, this obligation 


\section{Anthony Skelton}

conflicted in practice with utilitarianism and nothing he read in Mill convinced him of the rationality of sacrificing one's own happiness in order to promote the aggregate's happiness. ${ }^{7}$ He was stuck with a dualism of practical reason.

Sidgwick turned to Kant, one of his other masters, for inspiration. He agreed with Kant that there are categorical requirements of reason applying to rational agents irrespective of their desires (ME 7, 35; G 4:414-416). $\mathrm{He}$ appears to agree with Kant that the recognition that some act is right arouses in rational agents a motivation to do it (ME 34; KpV 5:47ff.). Sidgwick was, he said, especially "impressed with the truth and importance of. .. [Kant's] fundamental [categorical imperative] principle:-Act from a principle or maxim that you can will to be aniversal law" (ME xix; italics in original; also 210; G 4:402, 421, 437; KpV 5:69-70).

Sidgwick was not that impressed, however. He dissents from Kant's principle in two main ways. First, he does not think Kant's maxim is sufficient to cover the whole of morality. Thinking that "all particular rules of duty can be deduced from. . . [this] one fundamental rule ... appears to me an error analogous to that of supposing that Formal Logic supplies a complete criterion of truth" (ME 209-210; also xix). The main function of this fundamental rule is to

protect ourselves against the danger which besets the conscience, of being warped and perverted by strong desire, so that we too easily think that we ought to do what we very much wish to do. For if we ask ourselves whether we believe that any similar person in similar circumstances ought to perform the contemplated action, the question will often disperse the false appearance of rightness which our strong inclination has given to it.

(ME 209; also 319, 380) ${ }^{8}$

Second, Sidgwick says he is keen on the idea that "whatever is right for me must be right for all persons in similar circumstances" (ME xix; also 209,318 ). But he concedes that he does not accept this truth in the "precise form in which he [Kant] stated it" (ME 210n2; also 486). What he accepts is in fact a very slim principle:

it cannot be right for $A$ to treat $B$ in a manner in which it would be wrong for $B$ to treat $A$, merely on the ground that they are different individuals, and without there being any difference between the natures or circumstances of the two which can he stated as a reasonable ground for difference of treatment.

(ME 380; also 209, 496)

He takes this to be self-evident ( $\mathrm{ME} \mathrm{380;} \mathrm{also} \mathrm{318).} \mathrm{The} \mathrm{practical}$ upshot is that "an act, if right for any individual, must be right on 
general grounds ... for some class of persons" (ME 486; italics in original).

Sidgwick had, of course, turned to Kant for help in trying to deal with the fact that duty and self-interest are in practice often not coincident. As in the case of Mill, and unsurprisingly, the principle Sidgwick agreed to in Kant did not, Sidgwick felt, "meet" the difficulty that perplexed him (ME xx): "it did not settle finally the subordination of Self-Interest to Duty" (ME xix).

On Sidgwick's reckoning the egoist could easily will his own principle as a universal law for all rational beings:

He might say, "I quite admit that when the painful necessity comes for another man to choose between his own happiness and the general happiness, he must as a reasonable being prefer his own, i.e. it is right for him to do this on my principle. No doubt, as I probably do not sympathise with him in particular any more than with any other persons, I as a disengaged spectator should like him to sacrifice himself to the general good: but I do not expect him to do it, any more than I should do it myself in his place."

$(\mathrm{ME} \mathrm{xx})^{9}$

Moreover, Sidgwick's qualifications of Kant's "truth" led to quite significant differences in many of their most important practical moral conclusions. The next two sections outline two of the sharpest of those disagreements.

II

Kant and Sidgwick disagree sharply about the permissibility of lying. Kant holds that lying is always wrong because, on his own understanding of his principle, maxims on which, say, one makes statements one knows to be false in order to get oneself out of a jam, cannot be willed as universal laws (G 4:402-403, 4:422; KpV 5:69). One cannot will that one lie in order to convince someone to lend one money when there is no other way to get it. According to Kant, such a maxim is self-contradictory, for it is impossible to achieve the purpose of getting oneself out of a jam by lying if it is a universal law of nature that people lie in such cases.

Sidgwick has a laxer approach to lying (ME 315-316, 448). He maintains that even when you cannot "Act as though the maxim of your action were to become a universal law of nature," it does not follow that your action is wrong (ME 318). It might be the case that in one's circumstances one's maxim is not (or will not be) universally accepted, making it possible for one to produce more benefit by doing what cannot be willed as a universal law of nature. Sidgwick notes that it may appear that lying is ruled out by the "ethical axiom" that "what 
is right for me must be right for "all persons under similar conditions'" (ME 318). But if the situation is such that one's maxim is not or will not be universally adopted and one's lie is all told beneficial, then it is permissible to lie by the criterion.

Kant is, of course, unlikely to be moved by this (KpV 5:69-70). Sidgwick's best tack is to point out that common sense holds that it is permissible, if enough good is at stake, to do something-lie-that cannot be willed as a universal law for all rational beings. He rightly points out that

if we may even kill in defence of ourselves and others, it seems strange if we may not lie, if lying will defend us better against a palpable invasion of our rights: and Common Sense does not seem to prohibit this decisively.

(ME 315)

Common sense seems to concede in other cases that when enough good is at stake lying is permissible (ME 316). In which case, Kant's view of lying might well be counterintuitive.

Sidgwick, of course, has his own problems capturing common sense. He has to argue that in any case in which lying is all told beneficial one is permitted to lie. But Kant is likely right that it is wrong to lie in order to get someone to lend you money even if it is all told slightly more beneficial to lie. Common sense does not admit that if lying yields slightly more benefit than not, it is permissible to lie. Common sense might admit that lying is permissible only to prevent a "palpable invasion of our rights" or cognate invasion. The best Sidgwick can do to save his view is argue that indirect utilitarian considerations capture the commonsense view in its entirety (ME xxiii, 424ff.). But the possibility of this remains, at best, uncertain.

Sidgwick might not see the force of Kant's position on lying because for the most part he ignores the humanity formulation of the categorical imperative, requiring agents to "Act in such a way that you treat humanity, whether in your own person or in any other person, always at the same time as an end, never merely as a means" ( $G$ 4:429; also KpV 5:87). Lying involves using another as a mere means to an end because it involves bypassing their will to pursue an end that they do not (or cannot) share and so treating them (merely) like an instrument at your disposal. Kant claims that humanity or rational nature-the capacity for morality (MS 6:434)-is the objective value on which this formulation is based; the value of humanity constrains what it is permissible to do in the service of one's goals ( $\mathrm{G} 4: 428-429 ; \mathrm{KpV} 5: 131-132$ ). Kant thinks that rational nature is a "self-sufficient" end ( $G 4: 437)$.

It is possible that Sidgwick fails to contend with the humanity formulation because he misunderstands the nature of a self-sufficient or, as he calls it, a self-subsistent end (ME 380). Sidgwick thinks of an 
end as something to be promoted, e.g., pleasure or knowledge (ME $390 ; 1902,274-5)$. He fails to see that for Kant the end of humanity or the capacity for morality is an end that constrains or limits what we may do to each other. Humanity is to be respected or honored rather than promoted. We are not permitted to use humanity as a mere means to an end, however worthy that end may be. This prevents lying since deceiving someone involves treating them as a mere means.

Sidgwick might confess to failing to see the nature of a self-subsistent end while denying that this makes a difference to his rejection of Kant's view on lying. Kant holds that the universal law formulation of the categorical imperative and the humanity formulation are in fact identical or that the one reduces to the other ( $G 4: 436)$. The view is that when one wills one's maxims as a universal law for all rational beings one is constraining one's behavior by reference to what other agents can permissibly act on. Willing only what can function as a law for all rational beings involves treating rational beings as constraints on what it is permissible to will and therefore involves treating them as ends.

Sidgwick might argue, then, that in so far as he rejects the universal law formulation he rejects the humanity formulation, since he is in effect arguing that what can only serve as a law for all rational agents is not a constraint on what it is permissible for one to do and therefore he rejects the claim that rational nature is an absolute constraint on lying.

However, it is possible that the two formulations are not the same, and that the humanity formulation of the categorical imperative contains resources that the universal law formulation does not. ${ }^{10} \mathrm{Kant}$ would, then, be a kind of pluralist. Pluralism seems contrary to Kant's general orientation, however. The Groundwork, he says, "aims . . . to seek out and establish the supreme principle of morality" ( $G 4: 392$; italics in original; also 4:421, 4:440). In the Lectures on Ethics, he claims that "[w]here there are already many principles in ethics, there are certainly none, for there can only be one true principle" (LE 27:266; also MS 6:224). In any case adopting pluralism would be unlikely to matter to Sidgwick, given his general attitude to lying (not to mention pluralism) and so (it seems) his general attitude to using others as mere means. He is likely to hold that it is more plausible that lying is warranted in some cases than that humanity is an absolute constraint on lying.

Kant does not always appeal to the humanity formulation of the categorical imperative to establish the impermissibility of lying. Consider, for example, the famous case of the inquiring murderer discussed in his essay "On a Supposed Right to Lie from Philanthropy." In this case a murderer arrives at your door inquiring about the whereabouts of your friend who is the murderer's target. If your friend is in your house, your obligation is to tell the murderer the truth: "[t]o be truthful (honest) in all declarations is ... a sacred command of reason prescribing unconditionally, one not 


\section{Anthony Skelton}

to be restricted by any inconveniences" (OSR 8:427; italics in original; also OSR 8:426, 8:429).

Most reply that this conclusion is absurd and even Kant's disciples try to block it (Korsgaard 1986; Varden 2010). After all, it cannot be wrong in this case to lie to protect a friend. Kant demurred. This is unsurprising. However, what is surprising is that when Kant argues that it is wrong to lie to the inquiring murderer, he does not appeal to the universal law formulation or to the humanity formulation of the categorical imperative. There is good reason for him to refrain from so doing. It would expose these versions of the categorical imperative to serious ridicule. If lying in this case would involve either using the murderer as a mere means or a failure to universalize, it would seem to be these factors not the lying that would be impugned.

In the case of the inquiring murderer, Kant argues that while lying to the murderer is wrong, the wrong is not done to the murderer. The murdered has no right to what one sincerely believes. Lying in this case is a wrong in general:

I . . . do wrong in the most essential part of my duty in general by such falsification ... I bring it about, as far as I can, that statements (declarations) in general are not believed, and so too that all rights which are based on contracts come to nothing and lose their force; and this is a wrong inflicted upon humanity generally.

(OSR 8:426; italics in original)

Sidgwick has two potential replies. First, he could suggest that even if lying to the murderer does affect the extent to which statements are believed, it might be worth the cost. By lying in such cases we might help to protect innocent lives and in addition protect ourselves from being employed by murderers to assist them in their task.

Second, he might argue that it is not clear in what way lying to murderers threatens the force of all rights based on contracts. The conditions for permissible lying to murderers would, after all, presumably not hold in the case of (most) contracts. It is not obvious how the fact that we have a permission to lie to inquiring murderers makes it the case that I have less assurance that you will not lie to me in the context of drawing up a contract to paint my house. Contracts are not obviously at issue in the case of the inquiring murderer.

Of course, Kant might have a point. Once we permit lying we subordinate truth to "other considerations" and this does damage to our assurance that each will sincerely express what each holds to be true "with respect to all unavoidable necessary statements in general" (OSR 8:429; italics in original). But how moved we are by this will depend on how compelling those other considerations happen to be, and to what extent (if at all) the damage to assurance affects contracts. 
In Practical Ethics, Sidgwick takes up the issue of the morality of lying in a number of places. In two essays on clerical veracity, he discusses the obligations that officiating ministers owe to their religious communities in the event that the former come sincerely to reject a core conviction of their religion. Sidgwick argues that while clergy may in preaching various religious doctrines-e.g., that Jesus was born of a virgin-or in reciting creeds take advantage of the full breadth of interpretations and various meanings in understanding their statements, they ought not to "utter ... hard, flat, unmistakable falsehood" $(1998,81)$. It would be wrong to profess belief in the virgin birth if a clergy member does not believe it. Sidgwick argues that "no gain in enlightenment and intelligence which the ... ministry may receive from the presence of such men can compensate for the damage done to moral habits, and the offence given to moral sentiments, by their example" (1998, 77; emphasis added).

This statement led Hastings Rashdall $(1897,138)$ to dub Sidgwick a "Kantian rigorist." Sidgwick might, then, in his writings in practical ethics come closer to Kant. But, in fact, Sidgwick repeats arguments familiar from the Methods, noting that

deception may legitimately be practised for the good of the person deceived. Under a physician's orders I should not hesitate to speak falsely to save an invalid from a dangerous shock. And I can imagine a high-minded thinker persuading himself that the mass of mankind are normally in a position somewhat analogous to that of such an invalid; that they require for their individual and social well-being to be comforted by hopes, and spurred and cured by terrors, that have no rational foundation.

(1998, 73-74; also ME 316)

Kant's worry about the corrosive impact of the permission to lie on assurance might, then, be well warranted. He might be right that there is a significant tension between the permission to lie and assurance with respect to all "unavoidable necessary statements." At best, Sidgwick can reply that this might just be a warning to be extra careful about articulating the conditions under or contexts in which lying is permissible, Sidgwick's so-called "similar conditions."

In fact, in another essay in Practical Ethics Sidgwick clarifies his position. In "Public Morality," he argues that there is no difference in the moral norms binding individuals and states. He argues that when there is divergence in the rules binding the two it is a result of differences in circumstances, not principles. He argues with respect to both states and individuals that "urgent need" and previous non-compliance with veracity on the part of those to whom one intends to lie are "required ... in order completely to justify a breach of veracity" $(1998,44)$. 


\section{Anthony Skelton}

In his own, more practical treatise, Kant stays with his view expressed in the Groundwork and elsewhere that lying is impermissible. However, he offers a different argument for the claim: "[t]he greatest violation of a human being's duty to himself regarded merely as a moral being . . . is the contrary to truthfulness, lying" (MS 6:429; italics in original).

Kant is clear that the wrongness of a lie has nothing to do with its harmfulness in terms of setbacks to the happiness or well-being of others or of oneself. The wrongness of lying does not rest on the fact that it is a violation of one's duties to others or that it is an error of prudence. Instead, in lying an individual "violates the dignity of humanity in his own person" (MS 6:429). This seems to follow from the fact that there is a tension between lying or intentionally communicating to others the contrary of what a speaker thinks and "the natural purposiveness of the speaker's capacity to communicate his thoughts" (MS 6:429).

Sidgwick misunderstands this argument, thinking it has something to do with lying being prohibited by a code of honor, and he argues (perhaps rightly) that it is not clear that such codes rule out all lying or that all lying is dishonorable and so a threat to dignity (ME 315). This argument misses the essential feature of Kant's explanation of the threat to dignity, however, namely, the view of the natural purposiveness of the capacity to communicate one's thoughts.

But Sidgwick's objection might be recast. It is not clear that or how the natural purposiveness of the capacity to communicate rules out all lying. At the very least more needs to be said about the nature of this purposiveness and (especially) its normative relevance.

Sidgwick and Kant are, then, in sharp disagreement over the permissibility of lying. Sidgwick is stubborn in permitting lying even if in only select cases. Kant seems equally persistent in his view that (in principle and in practice) lying is always wrong. ${ }^{11}$ Both have views that court conflict with common-sense attitudes toward lying.

III

Sidgwick's agreement with Kant's "fundamental principle" did not prevent disagreements over the requirements of beneficence, either. For Sidgwick, of course, beneficence is the whole of morality (putting egoism aside). He is committed to utilitarianism, which requires that agents "produce the greatest amount of happiness on the whole; that is, taking into account all whose happiness is affected by the conduct" (ME 411; also 1889,485 ). What he means is that morality requires the promotion of the greatest surplus of pleasure over pain for the aggregate of all sentient beings.

This is a demanding standard, as Sidgwick allows. It requires that individuals make extreme sacrifices for the benefit of others. Some think the 
demandingness impugns utilitarianism (see Hills 2010). Sidgwick tries at various stages to argue that the impartiality that utilitarianism requires in theory is muted in practice. On Sidgwick's reckoning, the principle of rational benevolence-that one ought to aim at good generally not merely at a particular part of it, giving equal value to equal quantities of happiness-is the "rational basis for the Utilitarian system" (ME 387). Right after he declares in favor of this principle, he quickly attempts to disabuse readers of the belief that it demands too much in practice. $\mathrm{He}$ remarks that

I before observed [ME 252-253] that the duty of Benevolence as recognized by common sense seems to fall somewhat short of this [principle]. But I think it may be fairly urged in explanation of this that practically each man, even with a view to universal Good, ought chiefly to concern himself with promoting the good of a limited number of human beings, and that generally in proportion to the closeness of their connexion with him.

(ME 382; italics in original)

In his discussion of the relationship between common-sense morality and utilitarianism, he reiterates that there is no "conflict" with the partiality of common-sense morality since the "practical application" of the "theoretical impartiality of Utilitarianism is limited by several important considerations" (ME 431). Sidgwick endorsed an indirect form of utilitarianism on which the general happiness is "more satisfactorily attained if men frequently act from other motives than pure universal philanthropy" (ME 413). The best motives are, for Sidgwick, the main rules (suitably modified) comprising common-sense morality.

Accordingly, Sidgwick argues on utilitarian grounds that one is permitted to give one's own good greater weight than the good of others and to give wide scope to one's own self-interest because of one's greater knowledge of one's own good and the means to securing it and because "it is under the stimulus of self-interest that the active energies of most men are most easily and thoroughly drawn out" (ME 431). In addition, he argues that it is "tolerably obvious" that it is conducive to the general happiness "that each individual should distribute his beneficence in the channels marked out by commonly recognized ties and claims" (ME 433).

We are permitted on this view to give greater weight to those with whom we have close relations and who have a special claim on our services, including our own children, our lovers, our friends and those in special need (e.g., the prudent poor or unexpectedly endangered). In this way some worries about demandingness might be deflected and utilitarianism thereby partially reconciled with common-sense morality. 


\section{Anthony Skelton}

However, it is not clear how plausible this is as a tack to ward off worries about demandingness. Some of Sidgwick's remarks suggest that it is not completely effective even given his indirect utilitarianism. He argues that, though partiality is permitted by utilitarianism in general, in cases of unforeseen calamity or emergency I am required to adopt utilitarian impartiality:

if I am made aware that, owing to a sudden calamity that could not have been foreseen, another's resources are manifestly inadequate to protect him from pain or serious discomfort, the case is altered; my theoretical obligation to consider his happiness as much as my own becomes at once practical; and I am bound to make as much effort as to relieve him as will not entail a greater loss of happiness to myself or others.

(ME 436)

This may be too demanding for common sense. It is not clear that common sense would grant that we are required in this case to be impartial as between our own good and another's. Common sense might allow one in calamity cases to give a bit more weight to oneself or one's intimates over strangers. Suppose that two people are hit by a calamity and are short on the resources needed to prevent (equal amounts of net) suffering to themselves, but it is not possible to help both. Suppose that one of the individuals whom you can help is your child and one is a complete stranger. It seems plausible that you are not required to be indifferent between saving your child or a stranger. It is permissible if not obligatory to prevent your child's suffering.

Common sense might permit deviations from this kind of impartiality in a different way. Suppose that I can save a stranger from suffering due to an unforeseen calamity, but that helping costs me slightly more than it benefits the stranger. However, I help nonetheless. Sidgwick calls this "self-sacrifice" and he agrees that common sense praises it (ME 431). He tries to reconcile this to utilitarianism in a number of ways. He might use the same arguments to deflect this worry about his unforeseen calamity principle. He says that we frown on such sacrifices when "the disproportion between the sacrifice and the benefit is obvious and striking" (ME 432). But this leaves open that in cases without such disproportion (like the one under discussion) common sense approves. Sidgwick notes that it is possible that we approve anyway "because such conduct shows a disposition far above the average in its general tendency to promote happiness, and it is perhaps this disposition that we admire rather than the particular act" (ME 432). But it is just as likely that we approve of the act itself apart from the disposition and that we approve of the disposition in advance of our knowledge of its impact on the promotion of
general happiness. 
Kant might offer a better account of the demands of beneficence. Sidgwick might be accused of offering a standard that is too exacting. Sidgwick says that he and Kant agree on the principle of rational benevolence (ME 386). But this is hard to believe, given what Kant actually says about the duty of beneficence.

Kant expresses a variety of standards of beneficence. In the Groundwork, the duty of beneficence is described variously as "a duty to help others [in distress] where one can" (G 4:398), a duty to contribute at least something to the well-being of those who experience "great hardships" or "distress" and can be assisted easily (G 4:423), and a duty to contribute to the happiness of others more generally as a requirement of treating humanity as an end ( $\mathrm{G} 4: 430$ ). Treating others as ends involves, as far as one can, furthering "the ends of others. For the ends of any person who is an end in himself must, if this idea is to have its full effect in me, be also, as far as possible, my ends" ( $G$ 4:430; italics in original). In the Critique of Practical Reason, Kant mentions in passing that it is wrong to look on the needs of others with "complete indifference" ( $\mathrm{KpV} 5: 69)$.

In general, it is unclear how much these standards demand. The very last one calls only for us not to be completely indifferent. It is possible that avoiding complete indifference is consistent with doing only very little for others. Have I avoided indifference if I promote the needs of others only very rarely when it is very easy for me to do so? To what extent I have avoided it will depend on what not being completely indifferent amounts to. But Kant says little about what complete indifference involves. It is hard to know what the general requirement to further others' happiness involves. It might be quite demanding. It will depend on how one interprets Kant's claim that an agent is to further the ends of others "as far as he can" (G: 4:430). It is possible that the first two standards from the Groundwork are quite demanding, though Kant gives no account of how much we are required to help others in distress or those experiencing great hardships. In one case he says that the obligation is to help when doing so is easy, so it seems that he does not intend anything terribly demanding.

Kant's most robust discussion of the demands of beneficence are found in the Metaphysics of Morals, where he states that

The happiness of others is ... an end that is also a duty ... I ought to sacrifice a part of my welfare to others without hope of return, because this is a duty, and it is impossible to assign determinate limits to the extent of this sacrifice. How far it should extend depends, in large part, on what each person's true needs are in view of his sensibilities, and it must be left to each to decide for himself. For, a maxim of promoting others' happiness at the sacrifice of one's own happiness, one's true needs, would conflict with itself if it were made a universal law. Hence this duty is only a wide one; the duty has in it a 


\section{Anthony Skelton}

latitude for doing more or less, and no specific limits can be assigned to what should be done.-The law holds only for maxims, not for determinate actions.

(MS 6:393; italics in original)

This suggests a very undemanding standard of beneficence. The strength of the obligation of beneficence rests, seemingly, on what an individual decides based on her view of her true needs. The standard seems to state that you should do something for the well-being or happiness of others, though how much is left largely up to your "sensibilities." The main idea seems to be that you should at least not be indifferent.

Kant also emphasizes that we are permitted to give quite significant priority to our own well-being or happiness over the well-being of strangers in discharging the duty of beneficence. He notes that

If one is closer to me than another (in the duty of benevolence) and I am therefore under obligation to a greater benevolence to one than to the other but am admittedly closer to myself (even in accordance with duty) than to any other, then it would seem that I cannot, without contradicting myself, say that I ought to love every human being as myself, since the measure of self-love would allow for no difference in degree.-But it is quite obvious that what is meant here is not merely benevolence in wishes, which is, strictly speaking, only taking delight in the well-being of every other and does not require me to contribute to it (everyone for himself, God for us all); what is meant is, rather, active, practical benevolence (beneficence), making the well-being and happiness of others my end. For in wishing I can be equally benevolent to everyone, whereas in acting I can, without violating the universality of the maxim, vary the degree greatly in accordance with the different objects of my love (one of whom concerns me more closely than another).

(MS 6:451-452; italics in original)

Kant is not clear on exactly how much greater weight one is permitted to grant to one's own happiness or well-being. But it seems from what he says that we may give quite a bit more priority to our own happiness. Kant might, then, easily be accused of developing a view of beneficence that is not demanding enough in the face of the needs of others and the capacity that many of us have to assist.

Kant ought to have developed a more demanding standard. He is, of course, no stranger to demanding moral standards. He marks out a distinction between perfect or narrow duties and imperfect or wide duties. Duties to refrain from suicide in order to avoid a miserable condition or from lying are perfect or narrow duties, allowing of no latitude in how and when they are discharged, while the duty of beneficence is an 
imperfect or wide duty which allows for latitude in how and when it is discharged ( $G$ 4:421-424). Respecting the requirements to refrain from suicide to avoid a miserable condition and from lying (as we have seen) can be very demanding. You are required to refrain from lying presumably even to save your own child from an inquiring murderer, and you are required not to kill yourself even if all that your future life promises is unbearable and irremediable suffering.

Perhaps fortunately a more stringent standard of beneficence may be extracted from Kant. He notes that in discharging one's duties of beneficence, sacrifice of part of one's well-being or happiness is required (MS 6:393, 6:453). He does not say exactly how much sacrifice is required. He seems to suggest that the extent of any sacrifice be left up to the individual's sensibilities. He can do better than this, lamentably, subjective standard.

In his discussion of the vice of avarice, the avoidance of which is a duty to oneself as a moral being, Kant suggests that "acquiring the means to living in excess of one's true needs" a mounts to "greedy avarice" and therefore to a "violation of one's duty (of beneficence) to others" (MS 6:432; italics in original). The suggestion is that greed involves keeping for oneself more than is required to satisfy one's true needs with the intention of enjoying it, and that it is wrong to do so because it is a violation of one's duty of beneficence to other people. By true needs Kant seems to mean "comforts necessary to enjoy life" (MS 6: 433). To deny oneself these, Kant suggests in his discussion of the vice of miserliness, is to "leave one's own true needs unsatisfied" (MS 6:432) and, he further suggests, to "come to need the beneficence of others" (MS 6:454). It is plausible that when Kant talks about requiring that one sacrifice part of one's happiness or well-being for others, he means that one sacrifices the part of one's happiness not related to one's true needs.

Perhaps, then, the duty of beneficence might involve (at least) obliging one to sacrifice one's resources that are in excess of what is needed to satisfy one's true needs in order to benefit others, where to benefit them involves providing for their true needs or the comforts necessary to enjoy life. This fits with the focus on "distress" or to what others "need" in his various discussions of beneficence (G 4:398, 4:423; KpV 5:69; MS 6:452, 6:453; LE 27:455) and on his injunction "not to avoid the places where the poor who lack the most basic necessities are to be found but rather to seek them out" (MS 6:457) (since this is important to cultivating compassion, a "means to promoting active and rational benevolence" (MS 6:456)). Of course, Kant holds that the closer one is to another the "greater" the claim or obligation of beneficence one has to that other, and so we have therefore greater duties to our own true needs and to the true needs of those to whom we have close ties (including our spouses, children, and friends). This in some way limits the demands of 


\section{Anthony Skelton}

beneficence to strangers and so might generate as a more plausible standard of beneficence than the one Sidgwick puts forward.

Still, this might reveal a quite demanding obligation both to those close to one and to strangers. It is plausible that if one thought clearly about what fell into the category of true needs, it would turn out that what is necessary to enjoy life would not include much of what forms the focus of the resources of most affluent people. Any account of true needs is going to leave many such people with quite demanding duties to the true needs of strangers (not to mention those to whom they are closest). This would be demanding even given Kant's view that perfect or narrow duties take precedence over wide or imperfect duties (such as the duty of beneficence).

Famously, Sidgwick rejects the general argument that Kant provides for the duty of beneficence. In a number of places, Kant argues that I am required to be beneficent to others because I cannot will as a universal law that I do not help others in distress or advance others' happiness, for when I am in need or in distress I will very much will that I be helped. According to Kant, a will that intended not to help others in distress would "be in conflict with itself, since many situations might arise in which the man needs love [that is, to be 'helped in case of need' (MS 6: 393)] and sympathy from others, and in which, by such a law of nature generated by his own will, he would rob himself of all hope of the help he wants" (G 4:423; also MS 6:393, 6:453).

Sidgwick argues against Kant that Kant cannot derive the duty of benevolence in this way. Sidgwick notes that the argument depends on an empirical claim, namely, that a man will want that others help him when he finds himself in distress. However, Sidgwick argues, it is possible to conceive of a man "in whom the spirit of independence and the distaste for incurring obligations would be so strong that he would choose to endure any privations rather than receive aid from others" (ME 389). And, moreover, Sidgwick says, even if we all as a matter of fact will that we be helped by others when we find ourselves in need, we can imagine that

a strong man, after balancing the chances of life, may easily think that he and such as he have more to gain, on the whole, by the general adoption of the egoistic maxim; benevolence being likely to bring them more trouble than profit.

(ME 389)

Kant could reply to this by reliance on the idea that we have true needs as autonomous beings. He may argue that the independent and the strong man cannot fail to will that others help them at least with respect to their true needs, since fulfilment of these are the preconditions for living as strong and independent beings. Strong and independent men must will 
that others help them with at least the necessities for maintaining strength and independence because they do not have complete control over these necessities or means, though they will that they have these means as part of willing their specific form of life. At least with respect to some of the necessities, only other agents have some control over them. And in so far as the strong and independent men will their form of life, they will the necessities or means and so will that others provide them when the strong and independent men find themselves in distress or are unable to obtain these necessities or means on their own. If they cannot fail to will that our true needs be met, Kant can deflect Sidgwick's objection. ${ }^{12}$ If one cannot fail to will that one's true needs be met when one is in need, one cannot refuse to benefit others in terms of their true needs when others are in distress.

Sidgwick and Kant disagree on the demands of beneficence. Sidgwick articulates a pretty demanding standard. Kant is not careful in his articulation of the requirement of beneficence. The most plausible account that might be extracted from Kant is quite demanding, though it is not perhaps as demanding as Sidgwick's account. Both offer views that challenge conventional attitudes respecting beneficence.

\section{IV}

Kant and Sidgwick disagree about the permissibility of lying and about the demands of beneficence. Their disagreements on lying and beneficence affect their practical recommendations. Their disagreements are not merely theoretical. How might these disagreements be dealt with in light of the need to achieve some consensus over what we ought to do in practice?

In reply to the disagreement, Kant might argue that he provides the best representation of common-sense moral thinking. We might think that providing the best representation of this thinking is a sure sign that a philosopher has secured the proper kind and degree of consensus. Kant claims in numerous places that the categorical imperative undergirds common-sense morality. In the Critique of Practical Reason he says

The rule of judgment under laws of pure practical reason is this: ask yourself whether, if the action you propose were to take place by a law of nature of which you were yourself a part, you could indeed regard it as possible through your will. Everyone does, in fact, appraise actions as morally good or evil by this rule.

$(\mathrm{KpV} 5: 69)$

In the Groundwork, he remarks, of the categorical imperative, that "Common human reason, when engaged in making practical judgements, also agrees with this completely and has that principle constantly in view" (G 4:402; also 4:404). 


\section{Anthony Skelton}

It is hard for Kant to sustain this position. He seemingly contradicts common-sense morality in his official views about lying and possibly about beneficence. It is far from clear that common-sense morality forbids lying in every case and that when it comes to beneficence it counsels only that we avoid complete indifference. He cannot credibly claim to be representing common-sense morality in these cases. He is revising it.

That Kant might be revising common-sense morality is actually a problem for him. He is famous for having accepted that each is equally capable of accessing and being motivated by the moral law (see Schneewind 1999). He was convinced of this by Rousseau:

I myself am a researcher by inclination. I feel the entire thirst for cognition and the eager restlessness to proceed further in it, as well as the satisfaction at every acquisition. There was a time when I believed this alone could constitute the honour of humankind, and I despised the rabble who knows nothing. Rousseau has set me right. This blinding prejudice vanishes, I learn to honour human beings, and I would feel by far less useful than the common laborer if I did not believe that his consideration could impart a value to all others in order to establish the rights of humanity.

(Bem 20:44; italics in original)

It is important for Kant to show that his principle underlies our common morality; otherwise, he might have to claim that the moral philosopher has special access to moral principles which s/he communicates to "the rabble." If Kant cannot show that the categorical imperative is the principle underlying common-sense morality, he either has to give up the principle in favor of one more representative of common-sense morality or give up attempting to represent common-sense morality and the claim that each of us is equally capable of figuring out and being motivated by the claims of morality. If he sticks with his principle, he cannot claim that "even the most ordinary human intelligence can easily be brought to a high degree of correctness and completeness in moral matters" (G 4:391).

This might be unfair to Kant. Kant's claim is that ordinary human intelligence exhibits a high but not perfect degree of correctness and completeness in moral matters. This presumably leaves room for the moral philosopher to play some role in correcting and completing our ordinary moral views. The philosopher might perfect it in some way. The problem is that Kant's corrections to and completion of ordinary moral views are not entirely agreeable.

Sidgwick suggests at points that his favoured principle best represents common-sense morality. He argues that common-sense morality is inchoately and unconsciously utilitarian (ME 424, 427, 453, 454, 462) and that utilitarianism solves the problems besetting common-sense morality 
(involving vagueness in and conflict between its various elements) in "general accordance with the vague instincts of Common Sense, and is naturally appealed to for such solution in ordinary moral discussions" (ME 425). Unfortunately, Sidgwick concedes that utilitarianism, not to mention egoism, conflicts with common-sense morality and that in part the philosopher's function is to "tell men what they ought to think, rather than what they do think" (ME 373). He notes that the limits of the philosopher's deviation from common sense are "firmly, though indefinitely, fixed" (ME 373). But it is far from obvious that Sidgwick's deviations fall within what escapes controversy.

If neither Kant nor Sidgwick is able to secure consensus using their favoured principles, how can moral disagreement be dealt with for the purpose of practice? In his most practical treatise on ethics, Metaphysics of Morals, Kant says the right view for practical ethical reasoning is the categorical imperative. He argues that

The supreme principle of the doctrine of virtue is: act in accordance with a maxim of ends that it can be a universal law for everyone to have.-In accordance with this principle a human being is an end for himself as well as for others, and it is not enough that he is not authorised to use either himself or others merely as a means (since he could then still be indifferent to them); it is in itself his duty to make man as such his end.

(MS 6:395)

So Kant's practical ethics is just an extension, and (in the broad sense) an application, of his theoretical ethics. As we have seen, Sidgwick disagrees with Kant's understanding of his own principle and, of course, Kant rejects Sidgwick's utilitarianism. In the Methods, Sidgwick remarks that in the face of disagreement like this, either one is reduced to a state of neutrality regarding the matter about which there is disagreement, or one has shown that those with whom one disagrees are more likely than one is to be in error:

if I find any of my judgments, intuitive or inferential, in direct conflict with a judgement of some other mind, there must be error somewhere: and if I have no more reason to suspect error in the other mind than in my own, reflective comparison between the two judgements necessarily reduces me temporarily to a state of neutrality.

(ME 342)

In the Methods, he was not reduced to a state of neutrality with respect to the things about which he and Kant disagreed and so did not yield to disagreement with Kant. This might have been due to the fact that Sidgwick thought that his many objections to Kant's arguments meant that 


\section{Anthony Skelton}

he is less likely to be in error than Kant. ${ }^{13}$ In this case he could carry on with his utilitarianism in practical ethics. ${ }^{14}$ That is certainly one way to go. However, there is another, more plausible way to do practical ethics. Sidgwick suggests this way in his book Practical Ethics which includes, among other things, lectures given before practical ethics societies.

In one lecture, Sidgwick recounts his experience with the Metaphysical Society, of which he was a member from 1869-1880. He says that the society broke down because the various sides in the controversies of which it treated were unable to come to agreement, and each, philosophically, "remained exactly where we were ... and no one being in the least convinced by any one else's arguments" $(1998,4)$. In part, the reason for the inability to overcome disagreement in the context of the Metaphysical Society was that the aim of such a society was to get to the bottom of the things on which it focused including the meaning of life and the essence of virtue $(1998,5)$.

In practical ethics, Sidgwick argues, it is easier to avoid what brought the Metaphysical Society to an end. This can be done by giving up "altogether the idea of getting to the bottom of things, arriving at agreement on the first principles of duty or the Summum Bonum" $(1998,5)$. This is possible in part because the focus of practical ethics is "not knowledge but action: and with this practical object it is not equally necessary that we should get to the bottom of things" $(1998,5)$. We can give up trying to defend or rely on utilitarianism or the categorical imperative. In so doing, he argues, it might be possible to "reach some results of value for practical guidance and life" $(1998,5)$.

Instead of trying to work out the most basic requirements of morality and then applying them to practical problems, we ought to stay as close as we can to the "region of middle axioms" $(1998,7)$. This region comprises, roughly speaking, the "broad agreement in the details of morality which we actually find among thoughtful persons who profoundly disagree on first principles, and among plain men who do not seriously trouble themselves about first principles" $(1998,6)$. The broad agreement coalesces roughly around the main rules of common-sense morality, including requirements of veracity and of beneficence, among others. The function of practical ethical thinking is, then, to

bring into a more clear and consistent form the broad and general agreement as to the particulars of morality which we find among moral persons, making explicit the general conceptions of the good and evil in human life, of the normal relation of man to his fellows, which this agreement implies.

$(1998,7 ;$ also 6$)$

One shape this form of reasoning takes is illustrated in what Sidgwick calls casuistry, or reasoning concerning "how far, in the particular 
circumstances of certain classes of persons, the common good demands a special interpretation or modification of some generally accepted moral rule" $(1998,12)$. This involves, among other things, dealing with exceptions to the requirement of veracity and the extent of the demands of beneficence. On Sidgwick's reckoning, refusal to deal with such problems would leave any approach to practical ethics

inadequate for the practical guidance of men engaged in the business of the world; since modifications of morality to meet the special needs of special classes of people are continually claimed, and more or less admitted by serious and well-meaning persons.

$(1998,12)$

This might be an anathema to Kant. But in fact it is not. First, Kant is a great admirer of common-sense morality so sticking with it is not contrary to his view. In addition, although Kant espouses strong views on lying, as recounted earlier, at one point he relaxes his view in line with Sidgwick's description of casuistry. He notes that it might, after all, be permissible to lie in cases in which "men are malicious":

it is true that we often court danger by punctilious observance of the truth, and hence has arisen the concept of the necessary lie, which is a very critical point for the moral philosopher. For seeing that one may steal, kill or cheat from necessity, the case of emergency subverts the whole of morality, since if that is the plea, it rests upon everyone to judge whether he deems it an emergency or not; and since the ground here is not determined, as to where the emergency arises, the moral rules are not certain. For example, somebody, who knows that I have money, asks me: Do you have money at home? If I keep silent, the other concludes that I do. If I say yes, he takes it away from me; if I say no, I tell a lie; so what am I to do? So far as I am constrained, by force used against me, to make an admission, and a wrongful use is made of my statement, and I am unable to save myself by silence, the lie is a weapon of defence; the declaration extorted, that is then misused, permits me to defend myself, for whether my admission or my money is extracted, is all the same. Hence there is no case in which a necessary lie should occur, save where the declaration is wrung from me, and I am also convinced that the other means to make a wrongful use of it. ${ }^{15}$

Note that Kant is here doing exactly what Sidgwick thinks it is important to do in practical ethics. Kant is sticking close to a conviction core to common-sense morality, that lying is wrong. He is then working out an exception to it for a particular class of person in a particular kind of 


\section{Anthony Skelton}

circumstance. Note, too, that he says that this exception is a critical point for a moral philosopher, suggesting that he or she might have some special role to play in working out the correct view.

Second, Kant himself leaves us with lots of casuistical questions in the Metaphysics of Morals, which his own principle of practical ethics seems not to answer definitively. For example, he wonders whether one should reply honestly when one's colleague asks about the quality of his work (MS 6:431). He is wondering about exceptions to common-sense moral rules. To the extent that Kant leaves us with lots of such questions, he ought to join Sidgwick in his insistence on the importance of casuistry under strict conditions, not only because we want answers to such questions, but because, as Sidgwick remarks, it is likely that

there is a serious danger that when the need of such relaxations [of moral rules] is once admitted they may be carried too far . . . and no result could be more unfavourable than this to the promotion of ethical interest.

$(1998,13)$

Discussion of such exceptions may well be a solid protection of the rights of humanity.

Sidgwick notes that one purpose germane to his conception of practical ethics is to make the rules on which we agree "more explicit and clear than ... [they are] in ordinary thought" $(1998,6)$. Kant wonders, for example, about the extent of the demands of beneficence (MS 6:454). Sidgwick wonders the same $(1998,6,10)$. Sidgwick's claims about what is important to practical ethics should resonate with Kant, who himself had trouble working out a full view.

Sidgwick goes on to work out a view about the role of the philosopher and the plain man in practical ethics. The philosopher serves as a kind of moral expert in terms of clarifying the rules on which we agree. Her expertise is a function of her training (1998, 19-20). Unsurprisingly, the philosopher's job is not to work out her own favored position like utilitarianism or the categorical imperative and then to apply it in practice. This would invite the "dangers of sectarianism" and "conflicts" among rival moral factions $(1998,25)$. It would be disrespectful simply to force a moral view on others in the face of what appears to be perfectly reasonable disagreement (for more on this in Sidgwick, see Skelton 2006). The philosopher is of course to keep her reasoning focused on the "agreement among thoughtful persons," that is, the main elements of common-sense morality on which both Kant and Sidgwick draw.

What is the role for the plain man? Sidgwick's approach to practical ethics requires a "broad and comprehensive basis" $(1998,20)$. Accordingly, the plain man's "special moral experience" is something to which the moral philosopher ought to defer $(1998,23)$. Indeed, the moral 
philosopher "should always study with reverent care and patience... the Morality of Common Sense" $(1998,22$; also 22, 23). This is for two reasons. First, the philosopher lacks the plain man's "comprehensive and varied knowledge of the actual opportunities and limitations, the actual needs and temptations, the actually constraining customs and habits, desires and fears, of all the different species of that 'general man" to whom a view of right will apply $(1998,21)$. Second, the

judgements of practical men as to what ought to be done in particular circumstances are often far sounder than the reasons they give for them; the judgements represent the result of experience unconsciously as well as consciously imbibed; the reasons have to be drawn from that more limited part of experience which has been the subject of conscious observation, information, and memory.

(1998, 21-22)

Kant might dissent from the claim that the philosopher is some kind of moral expert. But given the training and the time philosophers have to devote to moral questions, it seems not unwarranted to think that they may be at least somewhat better placed than most others to perform certain forms of moral labor (e.g., articulation of moral rules and their exceptions) (Shaver 2012; Skelton 2014). The plain man, as Sidgwick points out, is not well placed to do that. Sidgwick dissents from Butler's claim that the plain man knows pretty much what to do in most practical contexts $(1998,6,23)$ on the grounds that matters in the world are a good deal more complex than they were in Butler's time. If this was true of Sidgwick's time $(1998,24)$, it is certainly true of our own, where commonsense morality is often perplexed by moral issues arising from the use of new technologies. Kant might seem to agree with Butler ( $G 4: 404)$. But Kant ought to agree that common sense cannot be our sole guide. He raises, as noted, many casuistical questions on which we are, to use Sidgwick's word, "perplexed." In addition, he concedes that in some sense the moral philosopher perfects the ordinary person's thoughts.

In general, Sidgwick's view provides a way to respect both the authority of the researcher/philosopher and the authority of the plain man. Each has their own "special" moral expertise to which each ought to defer. Sidgwick is quite insistent that the main features of common-sense morality aid and control the philosopher's constructions or clarifications of shared rules $(1998,23)$. This should appeal to Kant in part because of his view of the "correctness" and "completeness" of the ordinary man's views. He accords great respect to "common moral judgement" ( $G$ $4: 412)$. In addition, the insistence on respect in common-sense morality helps to ward off a worry that Kant has about the judgements of moral philosophers who "may easily be confused by a mass of strange and irrelevant considerations and caused to turn from the right path" (G 4:404). 


\section{Anthony Skelton}

But it leaves room for the philosopher to help, in cases where common sense is unclear on "perplexed," and where the philosopher's tools might well come in handy.

Sidgwick's general approach to practical ethics is respectful of reasonable disagreement. It offers a way forward in practical ethics that attempts to arrive at results that are both widely agreeable and useful in practice. Sidgwick's broad approach to practical ethics gives space to the judgement of the common person and to the philosopher. It is an attractive general model for how best to conduct practical moral reasoning in light of theoretical moral disagreements. Kant has good reason to agree. He notes that common-sense morality is important but that it leaves some things unanswered. He notes that the philosopher might have some role to play in clarifying and making up for the deficiencies, even if only slight, in the morality of common sense.

V

Sidgwick claimed Kant as one of his moral philosophical "masters." His engagement with Kant's ethics is sustained and fruitful. Sidgwick and Kant disagree on a great many moral issues in theory and in practice, including the morality of lying and the demands of beneficence. Neither offers a view that is completely agreeable. Dealing with the conflict between them (and others) in practice is important to making progress in solving practical moral problems. Sidgwick offers a way to handle disagreements in practice that is novel and interesting. Kant fails to deal effectively with disagreement in practical ethics. Sidgwick might well have something to teach his master. ${ }^{16}$

\section{Notes}

1. Sidgwick took a dim view of post-Kantian philosophers in general (Sidgwick and Sidgwick 1906, 233).

2. For the same claim about Sidgwick's objections to Kant on beneficence, see Hooker $(2000,347)$.

3. Immanuel Kant's works are abbreviated herein as follows: Bem $=$ Observations on the Feeling of the Beautiful and the Sublime and other Writings (Kant 2010); G = Groundwork for the Metaphysics of Morals (Kant 2002); $\mathrm{KpV}=$ Critique of Practical Reason (Kant 1997a); $\mathrm{LE}=$ Lectures on Ethics (Kant 1997b); MS = Metaphysics of Morals (Kant 1996a); OSR = "On a Supposed Right to Lie from Philanthropy" in Immanuel Kant: Practical Philosophy, ed. M. Gregor (Kant 1996b).

4. This objection is discussed in the chapters by Guyer and Nakano-Okuno in this volume. For earlier treatments, see, for example, Korsgaard (1996, 159-187), Timmerman (2007, 164-167), and Wuerth (2014, 247-254). For a penetrating defense of Sidgwick's thesis, see Fugate (2015).

5. Sidgwick also rejected Mill's qualitative hedonism (ME 94-95, 121).

6. For detailed accounts of Sidgwick's argument for utilitarianism, see Skelton (2008), Skelton (2010), Shaver (2014), and Crisp (2015). 
7. Sidgwick rejected Mill's appeals to sanctions to close the gap (ME 499-503). For discussion of Mill and Sidgwick on sanctions, see Harrison (2001). For Mill, see Mill (1969, 228-233).

8 . For the same sentiment, see Ross $(1954,9)$. The "great value" of Kant's universal law formulation of the categorical imperative, Ross writes, "lies in its putting us in the right attitude, by requiring us to ignore our own particular wishes and to adopt an impersonal point of view, in which we are less likely to be led astray by considerations of personal interest."

9. Sidgwick did not engage fully with Kant's attempts to deal with the conflict between duty and self-interest.

10. Kant could perhaps drop the universal law formulation. This might be plausible in light of the problem of false negatives to which Sidgwick refers (ME 487).

11. In MS, Kant wonders whether some lies are permissible in the Casuistical Questions he considers following his discussion of lying (MS 6:431). He considers whether one should reply honestly when one's colleague asks about the quality of the work she has produced. Kant does not clearly state a view. Some think in this case he favors lying (e.g., Parfit 2011, xliv). For more on this, see section IV.

12. For a similar proposal, see Herman (1984). Herman has a different account of true needs on which they amount to what is necessary to support the capacity to set ends in rational beings (586). The passages to which she points in Kant do not support her reading $(6: 392,6: 393)$. For more on Sidgwick's critique of Kant's derivation of the duty of benevolence, see Paul Guyer's chapter in this volume.

13. Sidgwick raises objections to many of Kant's views beyond those discussed here, including Kant's view that we have only an indirect duty to promote our own happiness (ME 386), that the good will is the only thing good without limitation (ME 222, 3.94-95) and that it does not involve an emotional element (ME 223), that we cannot promote others' perfection (ME 240), and that we have only indirect duties to non-human animals (ME 241, 414, 431).

14. For more on Sidgwick's views on peer disagreement and how this pertains to his views on Kant, see Robert Shaver's chapter in this volume.

15. This contradicts Kant's official view discussed earlier in the case of the inquiring murderer. In that case the murderer means to make wrongful use of my declaration and the declaration of my friend's whereabouts is wrung from me.

16. I wish to thank Lisa Forsberg and Tyler Paytas for helpful comments on previous versions of this chapter and Corey Dyck and Dennis Klimchuk for helpful conversations about Kant's ethics.

\section{References}

Crisp, R. 2015. The Cosmos of Duty: Henry Sidgwick's Methods of Ethics. Oxford: Oxford University Press.

Fugate, C. D. 2015. "On A Supposed Solution to the Reinhold/Sidgwick Problem in Kant's Metaphysics of Morals." European Journal of Philosophy 23: 349-373.

Harrison, R. 2001, "The Sanctions of Utilitarianism." In Henry Sidgwick, edited by R. Harrison, 93-116. Oxford: Oxford University Press.

Herman, B. 1984. "Mutual Aid and Respect for Persons." Ethics 94: 577-602.

Hills, A. 2010. "Utilitarianism, Contractualism and Demandingness." Philosophical Quarterly 60: 225-242. 


\section{Anthony Skelton}

Hooker, B. 2000. "Sidgwick and Common-sense Morality." Utilitas 12: 347-360. Kant, I. 1996a. Metaphysics of Morals. Edited by Mary Gregor. Cambridge: Cambridge University Press.

Kant, 1. 1996b. Immanuel Kant: Practical Philosophy. Edited by Mary Gregor. Cambridge: Cambridge University Press.

Kant, I. 1997a. Critique of Practical Reason. Edited by Mary Gregor. Cambridge: Cambridge University Press.

Kant, I. 1997b. Lectures on Ethics. Edited by P. Heath and J. B. Schneewind. Cambridge: Cambridge University Press.

Kant, I. 2002. Groundwork for the Metaphysics of Morals. Edited by T. Hill, Jr. and A. Zewig. Oxford: Oxford University Press.

Kant, 1. 2010. Observations on the Feeling of the Beautiful and the Sublime and Other Writings. Edited by P. Frierson and P. Guyer. Cambridge: Cambridge University Press.

Korsgaard, C. M. 1986. "The Right to Lie: Kant on Dealing with Evil." Philosophy and Public Affairs 15: 325-349.

Korsgaard, C. M. 1996. "Morality as Freedom." In Creating the Kingdom of Ends, edited by C. M. Korsgaard, 159-187. Cambridge: Cambridge University Press.

Mill, J. S. 1969. Utilitarianism. In Essays on Ethics, Religion and Society, Volume $\mathrm{X}$ of the Collected Works of John Stuart Mill, edited by J. Robson. Toronto: University of Toronto Press.

Parfit, D. 2011. On What Matters, 2 vols. Oxford: Oxford University Press.

Passmore, J. 1975. A Hundred Years of Philosophy. Harmondsworth: Penguin.

Rashdall, H. 1897. "Professor Sidgwick on the Ethics of Religious Conformity: A Reply." International Journal of Ethics 7: 137-168.

Ross, W. D. 1954. Kant's Ethical Theory. Oxford: Oxford University Press.

Schneewind, J. B. 1999. The Invention of Autonomy. Cambridge: Cambridge University Press.

Shaver, R. 2012. "Ethical Non-naturalism and Experimental Philosophy." In Ethical Naturalism, edited by S. Nuccetelli and G. Seay, 194-210. Cambridge: Cambridge University Press.

Shaver, R. 2014. "Sidgwick's Axioms and Consequentialism." Philosophical Review 123: 173-204.

Sidgwick, A., and E. M. Sidgwick. 1906. Henry Sidgwick: A Memoir. London: Macmillan.

Sidgwick, H. 1873. "John Stuart Mill." Academy (May 15): 193.

Sidgwick, H. 1883. "A Criticism of the Critical Philosophy." Mind 8: 69-91.

Sidgwick, H. 1889. "Some Fundamental Ethical Controversies." Mind 14: 473-487.

Sidgwick, H. 1902. Outlines of the History of Ethics. Sth ed. London: Macmillan.

Sidgwick, H. 1905. Lectures on the Philosophy of Kant and Other Philosophical Lectures and Essays. London: Macmillan.

Sidgwick, H. 1981 [1907]. The Methods of Ethics. 7th ed. Indianapolis: Hackett.

Sidgwick, H. 1998. Practical Ethics: A Collection of Addresses and Essays. Edited by S. Bok. Oxford: Oxford University Press.

Skelton, A. 2006. "Henry Sidgwick's Practical Ethics: A Defense." Utilitas 18: 199-217. 
Practical Ethics in Sidguick and Kant 39

Skelton, A. 2008. "Sidgwick's Philosophical Intuitions." Etica for Politica/Ethics and Politics 10: 185-209.

Skelton, A. 2010. "Henry Sidgwick's Moral Epistemology." Journal of the History of Pbilosophy 48: 491-519.

Skelton, A. 2014. "On Henry Sidgwick's 'My Stations and its Duties'." Ethics 125: 586-591.

Timmerman, J. 2007. Kant's Groundwork of the Metaphysics of Morals: A Commentary. Cambridge: Cambridge University Press.

Varden, H. 2010. "Kant and Lying to the Murdered at the Door . . One More Time: Kant's Legal Philosophy and Lies to Murderers and Nazis." Journal of Social Philosophy 41: 403-421.

Wuerth, J. 2014. Kant on Mind, Action, and Ethics. Oxford: Oxford University Press. 